\title{
TRADUÇÃO, EVANGELIZAÇÃO E NEGOCIAÇÃO LINGUÍSTICA: UMA EXPLORAÇÃO INTERDISCIPLINAR ${ }^{1}$
}

\author{
Verónica Murillo Gallegos ${ }^{1}$ \\ Anna María D'Amore-1 \\ ${ }^{1}$ Universidad Autónoma de Zacatecas, Cidade do México, Zacatecas, México \\ Krisztina Zimányi² \\ ${ }^{2}$ Universidad de Guanajuato, Cidade do México, Zacatecas, México \\ Tradução de Sara Lelis ${ }^{3}$ \\ ${ }^{3}$ Universidade de Brasília, Distrito Federal, Brasília, Brasil
}

\section{Introdução}

A investigação tradutológica navega por múltiplas disciplinas nas quais a tradução está inserida no âmbito dos estudos humanísticos e sociais. Na linha de investigação que nos interessa explorar

${ }^{1}$ Esse artigo é um dos resultados do projeto UAZ-2016-37151 "Estudos da tradução e interpretação na América Latina e Caribe" registrado na Universidad Autónoma de Zacatecas, México. Foi publicado pela revista "Mutatis Mutantis" em 2018. A tradução para o português brasileiro foi autorizada tanto pela revista quanto pelas autoras, às quais agradeço. Referência bibliográfica do artigo em espanhol: Murillo Gallegos, Verónica; Zimányi, Krisztina e D’Amore, Anna María. "Traducción, evangelización y negociación lingüística: una exploración interdisciplinaria". Mutatis Mutantis, 11.1 (2018): 24-51. Sistema de revistas da Universidad de Antioquia. 22/04/2020. < https://aprendeenlinea.udea.edu.co/ revistas/index.php/mutatismutandis/article/view/326632/20789236> 
no presente trabalho, a tradutologia não só recorre a outras áreas e teorias multi- e interdisciplinares afins, por exemplo, as que integram a história cultural e seus vizinhos (Burke and Po-chia Hsia 2007), como também contribui para engendrar e retroalimentar disciplinas emergentes. $\mathrm{O}$ caso que nos propomos a considerar, aqui, é o do franciscano Bernardino de Sahagún, missionário na Nova Espanha de 1529 até 1590, ano de sua morte. Sahagún realizou um importante trabalho plasmado em extensos textos bilíngues náhuatlcastelhano: sua investigação etnográfica conhecida como Historia general de las cosas de la Nueva España, sua Postilla y Exercicio cotidiano, dirigida aos jovens missionários de índios, e sua recomposição de um diálogo que ocorreu em 1524 entre os chamados "Doze apóstolos franciscanos" e um grupo de sábios indígenas conhecido como Coloquios y doctrina christiana, ou também como Coloquios de 1524. Em todos esses trabalhos, declara Sahagún, interviram ativamente velhos indígenas como informantes de seus costumes e sua língua, e indígenas trilíngues (náhuatl-latim-castelhano) que foram formados desde pequeno pelos freis e, depois, no Colégio de Santa Cruz de Tlatelolco (fundado em 1536).

Sem entrar na discussão sobre a realização dos Coloquios de 1524 em data tão próxima à data da Conquista de Tenochtitlan (1521), queremos destacar que, durante o domínio espanhol, não havia lugar para negociações ideológica e política: Hernán Cortés ordenou aos índios que recebessem os freis e que entregassem seus filhos a eles para serem educados no cristianismo. Além disso, no diálogo, os missionários expuseram os temais centrais do evangelho para serem impostos aos índios e convencê-los de que suas antigas crenças eram erros que deveriam abandonar. No entanto, no propósito de apresentar o cristianismo aos índios, eram necessários tradutores e intérpretes, assim como era necessária uma negociação linguística entre os idiomas e culturas envolvidos com fins de comunicação. Desde uma perspectiva tradutológica, observa-se que os esforços de tradução refletem a insistência dos espanhóis para impor seus costumes, religião, idioma e pensamento aos povos indígenas nos territórios conquistados. Para estudar esse fenô- 
meno, infelizmente, os moldes de tradução eurocêntricos, baseados na tradição clássica judaico-cristã, são limitados: diante da complexidade da relação entre indígenas e espanhóis na Nova Espanha, toda deliberação sobre definição, natureza, agente, produto ou processo da tradução apresenta-se reduzida (Icíar, Baigorri and Payàs 2008; Samaniego et al. 2012). A isso acrescentamos, recorrendo à classificação de Roman Jakobson (1959), que a negociação entre a expressão de cosmovisões abarcou tanto a tradução intralinguística, a exegese das escrituras que se pode classificar dentro da hermenêutica, como a tradução interlinguística, em nosso caso entre o castelhano e o náhuatl, além da tradução intersemiótica, dado que as línguas indígenas não estavam codificadas no alfabeto, mas sim em expressões iconográficas.

Atualmente, podemos observar que a separação entre tradução - como traslado de um texto escrito de um idioma a outro, e interpretação — como intervenção linguística oral entre dois idiomasse manifesta ao extremo entre contextos profissionais e profissionalizantes (AIIC 2012; European Commission 2009) em parte devido à ênfase posta pelos especialistas com formação em tradução e/ou interpretação, os quais trabalham em locais oficiais como a Organização das Nações Unidas ou a União Europeia, em seu empenho pelo reconhecimento público de sua profissão e, em parte, porque tal diferenciação se sustenta por forças de mercado e cursos de universidades consagradas em idiomas com suficiente poder sóciopolítico-econômico. Isso contrasta com o que acontecia na época colonial ibero-americana quando não só não se distinguia profissionalmente entre o trabalho de tradução e o de interpretação, mas sim quando, além dessas, os missionários desenvolveram outras atividades de maneira simultânea e complementária: aprenderam as línguas indígenas dos falantes nativos, realizaram amplos registros etnográficos e geográficos, formavam outros religiosos, gerenciavam recursos para sua empresa, doutrinavam indígenas e preparavam alguns deles segundo a gramática e outras disciplinas para apoio do trabalho missionário. Em certos casos, participaram inclusive como intérpretes nos tribunais da Nova Espanha, e foram 
parte ativa na conformação das políticas linguísticas para o Novo Mundo, ambos ocorridos dentro de um contexto colonial e com significativas dificuldades nascidas da incomensurabilidade linguística e cultural.

O objetivo desse artigo é projetar de que maneira a tradutologia, a linguística e a filosofia podem colaborar para oferecer uma análise apropriada da evangelização durante a época colonial, locus onde se mostram as vidas da negociação linguística que teve de ser realizada para ensinar a doutrina cristã aos nativos, com o objetivo de convertê-los, assim como seus obstáculos. Realizaremos esse objetivo oferecendo, primeiro, um panorama do estado da questão dos estudos sobre a evangelização para mostrar a necessidade de um enfoque interdisciplinar. Em seguida, exporemos a problemática tradutológica do caso em questão para, por fim, centrar-nos em um caso, a tradução da doutrina cristã para a língua náhuatl no auge da Nova Espanha, analisando dois exemplos de tradução retirados dos Coloquios de 1524 desde as perspectivas indicadas.

\section{Evangelização como objeto da linguística}

A tradução é, talvez, uma das ciências mais jovens que emergiram dos diversos estudos interessados pela linguagem desde o século XIX, os quais abarcam desde os estudos bíblicos ao que, em filosofia, se denominou giro linguístico e transitam desde a poética e a linguística, até a ética do discurso. De todos eles, cabe destacar a rápida consolidação da linguística cujo desenvolvimento teóricoconceitual não poucas vezes esteve estreitamente vinculado a campos como o da filosofia, da história, da antropologia, da sociologia e de outros âmbitos cujas expressões pós-pós-modernas dos interstícios de mudança de século definiram a tradução ao mesmo tempo que receberam dela novas possibilidades de estudo. Os estudos de tradução com bases linguísticas, estudos tanto descritivos quanto sociolinguísticos, avançaram junto com os estudos bíblicos para explorar temas relacionados à evangelização. Sobre o caso que abordamos 
neste artigo, desde 1947, com a publicação do livro La conquista espiritual (Ricard 1986), a evangelização durante a época colonial vem sendo objeto de atenção de historiadores, antropólogos e linguistas. Antropólogos e linguistas são os que, ultimamente, mais se aproximaram a algumas questões que surgem em torno da tradução com fins de evangelização, apesar de que a denominada "linguística missionária" acaba de iniciar sua etapa de formação e está em vias de consolidação como disciplina no auge do século XXI.

$\mathrm{Na}$ chamada para o VIII Congresso Internacional, em 2016, a Sociedade Europeia de Estudos de Tradução (EST, sigla em inglês) convidou os participantes a mobilizar fronteiras e/ou limites (Translation Studies: Moving Boundaries). Dentro do congresso, foi realizada uma sessão em modalidade de pôster sob o título $\mathrm{Me}$ diators of the divine: Rethinking the concept $f$ 'interpreter' in light of interpreting in religious contexts (Hokkanen and Downie 2016) para explorar os limites difusos entre os papéis desempenhados por intérpretes em contextos religiosos. Terreno frutífero para estudos em torno da tradução e da interpretação, o tema deste pôster é reflexo do crescente reconhecimento atual da necessidade de uma ampla conceitualização do papel dos intérpretes, que desempenham não só uma função linguística, mas também o papel de mediadores entre culturas e, inclusive, "mediadores do divino".

O pôster mencionado foi realizado dentro do congresso da EST na Dinamarca a poucos meses da realização, em Manila, do IX Congresso Internacional de Linguística Missionária. Esse foi um evento bianual desde 2010, e o propósito de sua criação na Noruega com a realização do primeiro congresso em 2003 consistia em reunir investigações sobre a metodologia, meta-historiografia, e antecedentes históricos e culturais da linguística missionária. Zwartjes e Hovdhaugen foram os responsáveis por um importante passo com vistas à sua consolidação como disciplina com a edição do livro dos anais desse primeiro encontro internacional. Com o título Missionary Linguistics/Lingüística misionera (Zwartjes and Hovdhaugen 2004), a edição constitui uma coleção importante de estudos sobre os textos linguísticos da recente modernidade e si- 
naliza a pauta para um bom número de investigadores sobre temas de gramática e lexicografia, tanto descritivos como comparativos, desde distintas perspectivas e de diferentes religiões, sobre línguas indígenas da América, Austrália, África e Ásia. Nesses anais, os autores descrevem o que sabemos sobre o sucesso na Nova Espanha, bem como em outras partes do mundo no período de expansão europeia e envio de missionários com fins colonialistas: foi apresentada a necessidade de produzir gramáticas e dicionários das línguas indígenas já que foi decidido que os primeiros missionários europeus utilizariam essas línguas como meio de cristianização. Os autores propõem que, no final do século XX, o estudo desses materiais linguísticos ainda não havia recebido atenção suficiente no campo da historiografia linguística. Essa mesma carência foi percebida no nosso entorno imediato não obstante a herança colonial do México e a generalização dos estudos da Nova Espanha em programas e planos de estudo em história e em literatura (cabe sublinhar que poucos anos antes, no ano 2000, havia sido fundada a Sociedade Mexicana de Historiografia Linguística).

Enquanto define-se o papel fundamental do tradutor-intérprete na composição dos textos linguísticos modernos dos missionários e seus colaboradores, não é senão até dez anos mais tarde que se torna explícito o referido papel na incipiente linguística missionária, e que ele é reconhecido no título dos anais do VII Congresso: Missionary Linguistics/Lingüistica misionera V: Translation theories and practices (Zwartjes, Zimmerman and Schrader-Kniffki 2014). Os estudos que integram esse volume especial compilam e analisam informações de descrições etnográficas e catecismos bilíngues e resgatam o trabalho lexicográfico dos missionários em contextos coloniais de dominação política e conquista espiritual. É uma das primeiras publicações que testemunham o fato de que os materiais bibliográficos missionários constituem uma fonte excelente para observar o papel da tradução na evangelização e no processo de aculturação e transculturação imposto pelos sistemas religiosos europeus, bem como para discernir as mudanças linguísticas impulsionadas durante as etapas coloniais através da criação 
de empréstimos e calcos do espanhol ou do latim em sua interação com as línguas indígenas, o que implicou mudanças semânticas nas línguas tanto dos vencedores como dos vencidos.

Junto com a realização do VII Congresso de Linguística Missionária e, por tanto, antes da publicação dos referidos anais, Zwartjes (2012) publicou um estado da questão da linguística missionária como subcampo da historiografia linguística. Assim como o que aconteceu nos estudos da tradução a partir dos anos 80, Zwartjes nota "a veritable explosion of research activities" na linguística missionária na primeira década do século XXI (Koerner 485 qtd. in Zwartjes 2). Na lista de referências presente em seu artículo, estão incluídas mais de 140 fontes primárias e mais de 300 fontes secundárias. Reconhece-se a proliferação de projetos e publicações, além dos louváveis esforços de difusão e digitalização das fontes missionárias tanto quanto o valor significativo dos avanços em geral neste campo. Em particular, Zwartjes reconhece a contribuição de Zimmerman (2004) por seu estado da arte preliminar da linguística missionária e sua participação em uma nova série editorial que surge nas mesmas datas, e que é de interesse para nosso trabalho.

O primeiro livro da série Koloniale und Postkoloniale Linguistik/Colonial and Postcolonial Linguistics (KPL/CPL), de Stolz, Vossmann e Dewein é publicado em 2011 pela editora De Gruyter. Considera-se a série representativa de uma nova subdisciplina da linguística, da linguística colonial e pós-colonial, que se propõe como uma linha inspirada nos trabalhos que são realizados dentro da linguística missionária e pela recente discussão sobre a linguagem, a linguística e o colonialismo. Nas palavras publicitárias da mesma editora: "The integration of these two perspectives in one approach makes 'Colonial and Postcolonial Linguistics' special”. A intenção da série é tornar acessível e comentar os textos que foram escritos sobre as línguas indígenas durante a época colonial europeia, bem como investigar como eles refletem o discurso político e cultural. Essa série abarca, em seu quinto número, as participações destacadas do VII Congresso de Linguística Missionária sob o título Colonialism and Missionary Linguistics, (Zimmerman and 
Kellermeier-Rehbein 2015), o qual reúne investigações sobre a linguística missionária em contexto coloniais africanos e americanos. Enquanto isso, também em 2015, mas do outro lado do mundo, foi publicado um número especial da revista Mutatis Mutandis que, por fim, resultaria na publicação de um livro com o mesmo título: El escrito missioneiro como medicación intercultural de carácter multidisciplinar (Vega and Pulido 2016).

Estas publicações demonstram o recente e crescente interesse pelos temas da linguística missionária relacionados a problemas da tradutologia e da historiografia linguística, o qual é fruto do trabalho colegiado de grupos de investigação a partir de colaborações internacionais e interinstitucionais. Podemos destacar o trabalho de alguns como o grupo "Revitalizing Older Linguistic Documentation" (ROLD), equipe de investigação do Centro de Linguagem e Comunicação de Amsterdam, que foi promotor na realização dos Congressos de Linguística Missionária, e outros coletivos de investigação de universidades europeias e latino-americanas que contam com colaborações em redes internacionais, como o Grupo Alfaqueque da Universidade de Salamanca e o grupo HISTRAD de Universidade de Alicante. Nas Américas, enfatizamos o trabalho da agrupação Fronteira de Línguas da Universidade Católica de Temuco, e do grupo História da Tradução na América Latina (HISTAL) da Universidade de Montreal, que conta com a participação de estudiosos de vários países latino-americanos, ao documentar e difundir escritos e projetos do continente fundamental para o desenvolvimento dos estudos da tradução e intepretação na América Latina. Isso sem esquecer da destacada atividade da supracitada Sociedade de Historiografia Linguística (SOMEHIL), que abre espaços de diálogos entre estudiosos da língua com linhas pertinentes para o tradutólogo. A interação entre eles foi frutífera graças aos encontros que fomentaram a investigação, e impulsionaram a publicação de seus resultados.

Não é o propósito deste artículo mencionar todas as publicações e todos os projetos que são pertinentes para o campo da linguística missionária em sua imbricação com os estudos da tradução

Cad. Trad., Florianópolis, v. 41, $\mathrm{n}^{0}$ 1, p. 303-343, jan-abr, 2021. 
e interpretação na América Latina, mas gostaríamos de enfatizar que, além do antes mencionado número especial desta revista, há projetos importantes como o denominado Glosas Croniquenses, e publicações chave que podem ser consultados através do site da HISTAL (Bastin 2003; Payàs, Zavala, Samaniego and Garbarini 2009; Payàs and Zavala 2012) onde se propõe com clareza a necessidade de abordar o tema da tradução no auge da modernidade, especialmente nas colônias, a partir da interdisciplinariedade. Em consonância, nosso propósito é realizar um trabalho multidisciplinar sobre os assuntos linguísticos durante o período da Nova Espanha, especialmente em casos de tradução, que nos posicione dentro do corpo crescente de estudos críticos sobre o tema (D'Amore, Murillo Gallegos and Zimányi 2016; Ríos Castaño 2014; Valdeón 2014; Zimmerman and Kellermeier-Rehbein 2015).

\section{Evangelização como objeto da filosofia}

No México, frequentemente acontece que, quando algum profissional da filosofia aborda a obra missionária de algum religioso (salvo que se trate de algum tratado filosófico-teológico), sua investigação é classificada sob o rótulo de "história" em livrarias e bibliotecas, o que dilui a influência que pudesse ter no âmbito filosófico. A filosofia no México enfoca-se, especialmente, em considerar os escritos missionários como testemunho da imagem que os espanhóis fizeram para si dos indígenas e do Novo Mundo (Frost 1996), como parte da defesa dos direitos do índio (Beuchot 1990; Rovira 2004), ou como discurso sobre a inclusão da América na histórica universal (Frost 2002). Ainda que todos eles se interessem pelas relações entre indígenas e religiosos, majoritariamente se centram em seus escritos e ideias, e pouco dizem da interação cultural além da análise dos interesses colonialistas e evangelizadores dos quais padece, ou dos problemas de comunicação interlinguística. Por sorte, recentemente surgiram alguns trabalhos de filosofia que atendem este aspecto (Anchondo 2014; Ríos Reyes 
2016) em que, apesar de já considerarem a questão dos idiomas da evangelização e seu papel no contato cultural, pouco se ocupam, em particular, da tradução não obstante proponham o conflito entre as cosmovisões envolvidas, a adaptação dos saberes dos freis para realizar seu trabalho e sua recepção pelos indígenas.

Felizmente, existem trabalhos de filósofos que, embora foram escritos em atenção a fins alheios à problemática colonial e de evangelização, podem ser aplicados ao tema da tradução para evangelizar. Tal é o caso de algumas filosofias da linguagem. Por exemplo, W. V. Quine, filósofo interessado na lógica e na ciência, propõe toda uma problemática em torno a um caso de tradução radical que ele imagina, a qual ocorre quando se enfrentam, pela primeira vez, dois povos que se desconheciam mutuamente, falam línguas diferentes, e devem se comunicar sem que haja intérpretes mediando. Quine obriga a pensar em tudo o que implica aprender um idioma alheio nesta situação. O mero estabelecimento de equivalentes linguísticos por ostentação de objetos, mediante imagens ou por sinais, se vê dificultado pela maneira diversa em que são agrupadas e nomeadas as percepções que cada povo tem do mundo. A despeito do interesse alheio à questão que nos ocupa, as abordagens do filósofo obrigam a pensar a situação vivida pelos freis da Nova Espanha desde uma nova perspectiva, cujos testemunhos encontramos vários exemplos do que Quine queria destacar: quando os indígenas chamavam de "Santa Maria" todas as imagens que os freis mostravam (Motolinía 37); o fracasso deles quando querem ensinar os nativos sobre a existência de um só deus, a bem-aventurança no céu ou sobre o inferno "por sinais (como mudos)" (Mendieta 363-364); ou quando os franciscanos aprendiam o idioma nahuatl das crianças e "o que hoje parecia que eles haviam entendido, amanhã parecia não ser assim" 2 (Mendieta 366).

2 Texto em espanhol: “lo que hoy les parecía habían entendido, mañana les parecía no ser así”.

Cad. Trad., Florianópolis, v. 41, n 1, p. 303-343, jan-abr, 2021. 
A filosofia da linguagem leva-nos a considerar outros problemas como os processos de codificação alfabética das línguas americanas, o conhecimento de suas particularidades gramaticais e a busca —ou invenção- de equivalentes linguísticos para compor um discurso que facilite a comunicação entre ambos os povos. Ao problematizar sobre as palavras e seu referente, em particular sobre os processos epistemológicos envolvidos na aprendizagem de uma língua e o estabelecimento de equivalentes em uma situação de tradução radical, Quine manifesta claramente a incomensurabilidade linguística (fonética, semântica e morfológica) e a cultural no caso inventado por ele. Isso requereria, além disso, para aplicá-lo no caso da evangelização Nova Espanha, que recorramos ao trabalho dos linguistas que se ocuparam especialmente dos idiomas nativos americanos e à influência na tradução do contexto político e religioso com vistas ao auge da modernidade. Assim, poderão ser entendidas algumas das dificuldades que talvez existiram para estabelecer equivalências entre a língua latina e o náhuatl, ou entre o náhuatl e o castelhano, ou o que alguns missionários talvez advertiram a seus leitores que não seguiram a ordem gramatical de Nebrija em suas artes da língua mexicana porque não ter declinações como o latim ou porque carece de artigos e outros distintivos de gênero e número (Olmos 15-16). Claro que deveriam ser inseridas outras considerações nas investigações sobre semântica filosófica, como as da pragmática ou a hermenêutica filosóficas, que conectam o linguístico com a ética, a antropologia e a filosofia política. Com elas será possível oferecer uma análise mais ampla e pertinente do fenômeno missionário que é nosso objeto (Murillo 2009), sobretudo quanto aos assuntos de compreensão intercultural, formação de identidades e o papel desempenhado pelos mediadores.

\section{Tradutologia e o caso da Nova Espanha}

Embora, atualmente, contamos com excelentes trabalhos sobre os discursos de evangelização compostos nas línguas indígenas predomi- 
nantes no antigo território da Nova Espanha, cujos autores frequentemente são, além disso, tradutores desses idiomas, poucos estudos abordam a complexidade desses textos desde uma perspectiva tradutológica. Em geral, somente enfatizam a colaboração de indígenas e missionários no referido trabalho e fazem interessantes precisões semânticas sobre as particularidades dos referidos idiomas. Isso obriga-nos a abordar, aqui, apenas a complexidade dessa problemática, e sublinhar a necessidade de um estudo interdisciplinar. Para tanto, tomamos como exemplo a obra do frei Bernardino de Sahagún.

Sobre o diálogo de 1524 entre missionários e indígenas, Sahagún menciona somente que foi realizado por intermédio de um intérprete, sem oferecer mais dados. No entanto, para sua composição adverte que se baseou em umas velhas anotações e no testemunho de alguns dos Doze, aos quais ele mesmo conheceu e cuidou, além de contar com ajuda dos indígenas estudantes do Colégio de Santa Cruz de Tlatelolco: "um se chama Antonio Valeriano, vizinho de Azcapulzaco, outro Alonso Vegerano, vizinho de Quauhtitlan, outro Martin Jacobita, vizinho desse mesmo Tlatilulco e Andrés Leonardo, também de Tlatilulco"3. Ademais desses, contou com a intervenção de "quatro velhos muito falantes, entendidos assim em sua língua como em todas suas antiguidades"4 (Sahagún 75) Esses apontamentos, e que o texto sahaguntino seja bilíngue (castelhano e náhuatl) advertem sobre o complexo processo de negociação linguística que deve ter acontecido para traduzir a doutrina cristã para o náhuatl, onde a intervenção conjunta de indígenas e franciscanos também deve ter provocado discussões sobre as melhores maneiras de traduzir a doutrina cristã para a língua mexicana e algumas tentativas de tradução dos temas fundamentais do evangelho. Os Coloquios de 1524 revelam que toda essa empresa requeria diversos processos linguísticos e culturais para que indígenas e missionários pudessem conversar,

\footnotetext{
3 Texto em espanhol: "uno se llama Antonio Valeriano, vezino de Azcapulzaco, otro Alonso Vegerano, vezino de Quauhtitlán, otro Martin Jacobita, vezino deste Tlatilulco y Andrés Leonardo, también de Tlatilulco".

${ }^{4}$ Texto em espanhol: "quatro viejos muy pláticos, entendidos ansí en su lengua como en todas sus antigüedades".
}

Cad. Trad., Florianópolis, v. 41, n 1, p. 303-343, jan-abr, 2021. 
para traduzir a mensagem cristã para a língua nahuatl e impô-la. Em outras palavras: a negociação linguística era imprescindível para implementar a religião cristã entre os nativos americanos, mas, como veremos, analisar esse caso apresenta alguns desafios para as categorias e conceitos tradicionais da tradutologia.

Para começar, interpretação e tradução foram processos simultâneos durante a aprendizagem da língua mexicana pelos missionários, e a composição dos primeiros discursos (orais e escritos) de evangelização que, como antes enfatizamos, se realizava paralelamente com outras atividades que repercutiram também no processo missionário. Isso dificulta a aplicação dos termos tradicionais da tradutologia ao caso em questão ao mesmo tempo que existe toda uma gama de conceitos na tradutologia contemporânea que podem ser empregados para o estudo desses casos. Recordemos que a análise etimológica da designação da tradução e a interpretação em uma série de idiomas revela que a maioria deles têm termos distintos para essas atividades, o que implica que são conceitualizados de diferente maneira: parece que, em vários idiomas, a interpretação, historicamente anterior à tradução, necessita a emissão de uma nomeação (Chesterman 2006). No emergente império espanhol, em particular, variavam bastante as denotações e conotações do intérprete durante e depois da conquista (Valdeón 40-41). Atualmente, é a noção de mediação que ocasiona ainda mais conflitos, pois em torno da interpretação persiste o debate sobre a conceitualização de seu papel e a designação da função do intérprete, que oscila entre "tradutor/ intérprete", "mediador (inter)cultural", "defensor", "trabalhador intercultural" (Phelan and Martin 2010; Pöchhacker 2008; Rudvin and Spinzi 2014; Shisheng and Shuang 2012; Zimányi 2009), entre outros que se podem dizer daqueles que intervieram na composição de textos do período colonial para evangelizar.

Outro enfoque pertinente para nosso caso é o que atualmente se observa com respeito às línguas não-ocidentais de menor predomínio, onde os tradutores-intérpretes na atualidade com frequência trabalham em várias modalidades e, portanto, deveria se 
levar em conta uma conceitualização do tipo "cluster" (Chesterman 2006), a qual reconhece a natureza multifacetária da atividade. Essa conceitualização não pode se restringir à uma categorização das principais modalidades da tradução embora abarquem tanto a tradução como a interpretação e, também, modalidades mistas (Hurtado 70-73). Apesar de que a base da taxonomia varia entre a modalidade, o contexto e o conteúdo (por exemplo, interpretação consecutiva, legendagem ou tradução de programas informáticos), a gama de modalidades resiste às limitações pela simples razão de que, com a emergência de novas tecnologias, surgem novos tipos de tradução com particularidades claramente distintas das do século XVI colonial. Em qualquer caso, não há escapatória para a interação de universos diversos devido ao êxodo de refugiados políticos e econômicos que não deixam de se arrastar para as praias da Europa e semelhantes entidades no mapa geopolítico mundial. Da mesma forma, para esse encontro, era necessária mediação linguística, pois há cinco séculos as ondas de migração iam no sentido oposto, ou seja, não eram os expropriados que chegavam em terras desconhecidas, mas sim os conquistadores.

Com relação ao agente da tradução, ao tradutor, persiste a perplexidade. Em países desenvolvidos do século XXI, a profissionalização da tradução e da interpretação avança em várias instâncias: por exemplo, a Autoridade Nacional de Credenciamento para Tradutores e Intérpretes ${ }^{5}$, uma empresa de propriedade governamental federal, assegura a qualidade da tradução e interpretação na Austrália; o Grêmio de Intérpretes na América (Interpreters' Guild of America, s.f.), uma organização independente, luta pela regularização da interpretação nos Estados Unidos; PACTE (vide também Hurtado 2017), um grupo de investigação colaborativa europeia encabeçado pela Universidade Autônoma de Barcelona, vem realizando um trabalho de desenho da estrutura e das competências do tradutor para a formação e credenciamento de tradutores. Esses esforços, quanto à padronização do trabalho do tradutor e intérprete,

${ }^{5}$ Autoridad Nacional de Acreditación para Traductores e Intérpretes (NAATI).

Cad. Trad., Florianópolis, v. 41, n 1, p. 303-343, jan-abr, 2021. 
são mais que legítimos e, definitivamente, necessários no ocidente no sentido pós-colonial (Saïd 1979) a fim de garantir a qualidade dos serviços. Em contrapartida, nos tempos da Conquista, geralmente refere-se ao missionário como autor dos textos e, embora os religiosos dão notícia da participação de indígenas, como é o caso de Sahagún, se conhece muito pouco sobre o processo de interpretação e tradução para compor um escrito bilíngue ou para traduzir a mensagem cristã para as línguas indígenas ou para a formação de ajudantes trilíngues para a evangelização.

Na Nova Espanha, como em nossos dias, também houve diversas ações e legislações encaminhadas para formar tradutores e intérpretes, e para regular seu trabalho. No entanto, isso não significou sempre que os intérpretes foram profissionais ou que tiveram formação adequada. Com efeito, os primeiros intérpretes foram capturados pelas tropas espanholas e, depois de uma estadia "educativa" no velho continente, retornaram com os conquistadores em campanhas posteriores. Como comenta Cuesta:

\begin{abstract}
Antes que Cortés começasse "de verdade" a Conquista da Terra Firme, outros espanhóis haviam tentado dominar Tenochtitlan. Embora fracassaram, tiveram que procurar "línguas" (intérpretes) para futuras expedições. Sabemos que, em 1517, Hernández de Córdoba capturou dois jovens indígenas de Yucatán que foram batizados com os nomes de Julián e Melchor, os quais ficaram com os conquistadores e aprenderam sua língua. $\mathrm{O}$ mesmo aconteceu com um rapaz de língua náhuatl capturado em 1518 por Juan de Grijalba e batizado como Francisco ${ }^{6}$ (Cuesta 3-6).
\end{abstract}

${ }^{6}$ Texto em espanhol: "Antes que Cortés comenzara en "serio" la Conquista de la Tierra Firme, otros españoles habían intentado hacerse con Tenochtitlán. Aunque fracasaron hubieron de procurarse "lenguas" (intérpretes) para futuras expediciones. Sabemos que en 1517 Hernández de Córdoba capturó a dos jóvenes indígenas de Yucatán a los que bautizó con los nombres de Julián y Melchor quienes se quedaron con los conquistadores y aprendieron su lengua. Igual le ocurrió a un mozo de lengua náhuatl capturado en 1518 por Juan de Grijalba y bautizado como Francisco". 
Os primeiros discípulos indígenas dos franciscanos foram também apanhados à força. Em 1523, apenas dois anos depois da vitória dos espanhóis sobre os astecas com a queda de Tenochtitlán, os três freis flamengos começaram seu trabalho na nascente Nova Espanha recrutando meninos indígenas para doutriná-los e para aprender deles a língua mexicana. Com a chegada dos Doze franciscanos no ano seguinte, os principais indígenas escondiam seus filhos e entregavam no lugar os filhos de seus servos. Em todo caso, esses meninos indígenas ensinaram seu idioma aos missionários, tentaram evangelizar seus próprios pais e acompanharam os missionários na destruição de tudo o que parecia idolátrico aos olhos espanhóis. Nas seguintes gerações, graças à interação multiétnica, cresceram meninos bilíngues ou multilíngues que, de maneira natural, emergiram depois como intérpretes. De todo modo,

as relações interculturais não são esclarecidas precisamente como aprendizagens de uns dos outros, em um clima de respeito e de compreensão das diferenças. Historicamente, prevaleceram enfrentamentos e confrontações, ou seja, relações onde uns impõem aos outros sua visão das coisas ou, para ser mais exatos, seus interesses ${ }^{7}$ (Chiodi \& Loncon 174)

Mais que um simples centro de educação superior para os índios, o Colégio Santa Cruz de Tlatelolco (fundado em 1536) desempenhava o papel de formador de tradutores, consultores linguísticos, copistas e informantes indígenas, e como lugar onde eram produzidas todas as obras missionárias da Nova Espanha subscritas por franciscanos, como afirma Sahagún:

\footnotetext{
${ }^{7}$ Texto em espanhol: "las relaciones interculturales no se despliegan precisamente como aprendizajes los unos de los otros, en un clima de respeto y de comprensión de las diferencias. Históricamente más bien han prevalecido enfrentamientos y confrontaciones, o sea relaciones donde los unos imponen a otros su visión de las cosas o más bien, para ser más exactos, sus intereses".
} 
porque se foram feitos sermões, glosas e doutrinas em língua indiana, que podem parecer e sejam limpos de toda heresia, são precisamente o que com eles [os indígenas colegiais de Tlatelolco] foram compostos e, eles, por serem entendidos na língua latina nos dão a entender as propriedades dos vocábulos e as propriedades de sua maneira de falar, e as incongruências que falamos nos sermões, ou as que dizemos nas doutrinas; eles fazem as correções para nós, e qualquer coisa que deva ser convertida em sua língua, se não for com eles examinada, não pode ir sem defeito sem escrever congruamente na língua latina, nem em romance, nem em sua língua; no que se refere á ortografia e boa letra, não há quem escreva senão aqueles aqui educa$\operatorname{dos}^{8}$ (Sahagún 567).

Não há dúvida da natureza problemática desse fenómeno (Martinez, McClure and Eddy 2009). Por um lado, em atenção ao conceito da tradução (e interpretação) natural, promovido por Harris (1976, 2012), libera-se das restrições dos esforços padronizados e aceita-se a espontaneidade do processo de se tornar intérprete e tradutor. Há numerosos proponentes da mediação por meninos, ou child language brokering (CLB, sigla em inglês) (Morales and Hanson 2005), que argumentam que a experiência de interpretar como jovem eleva a autoconfiança dos meninos (Antonini 2010; Faulstich Orellana 2009). No entanto, outros autores advertem dos efeitos negativos de realizar um trabalho com tanta responsabilidade legal, informativa e emocional sem nenhuma formação nas técnicas

${ }^{8}$ Texto em espanhol: "porque si sermones y postillas y doctrinas se han hecho en la lengua indiana, que pueden parecer y sean limpios de toda herejía, son precisamente lo que con ellos [los indígenas colegiales de Tlatelolco] se han compuesto, y ellos por ser entendidos en la lengua latina nos dan a entender las propiedades de los vocablos y las propiedades de su manera de hablar, y las incongruidades que hablamos en los sermones, o las que decimos en las doctrinas; ellos nos las enmiendan, y cualquiera cosa que se haya de convertir en su lengua, si no va con ellos examinada, no puede ir sin defecto sin escribir congruamente en la lengua latina, ni en romance, ni en su lengua; para lo que toca a la ortografía y buena letra, no hay quien lo escriba si no es los que aquí se crían”.

Cad. Trad., Florianópolis, v. 41, $\mathrm{n}^{0}$ 1, p. 303-343, jan-abr, 2021. 
de interpretação, terminologia especializada ou ética profissional (Umaña-Taylor 2003, entre outros). Em todo caso, desde o começo, e sempre acompanhados por indígenas, as relações entre eles e os religiosos para compor textos missionários foram mudando à medida em que os freis conheciam melhor a língua e a cultura nahuas, somavam experiências com os indígenas, e as políticas espanholas frearam o trabalho das ordens religiosas no Novo Mundo.

A isso é somada uma política real oscilante que tão logo ordenava a castelhanização desses indígenas, em detrimento de seus idiomas, que a criação de alguma cátedra das línguas indígenas mais comuns nas colônias (Wright 2007) e as disposições tridentinas sobre a tradução e composição de textos religiosos, patentes na "Consulta sobre quais livros religiosos estão traduzidos em línguas indígenas e se os índios podem tê-los"9 de 1572 (Fernández 8185). Aqueles que estavam em posição de poder também tentaram regularizar as atividades da interpretação menos de uma década depois da conquista da Nova Espanha (Grupo de Investigação T-1611 $2007^{10}$ ). As leis das Índias que foram compiladas pela ordem de Carlos III em 1776, e seguiam vigentes no século XIX, estabeleceram as condições laborais dos intérpretes, além de que prescreveram o ofício a fim de garantir a imparcialidade, confidencialidade e neutralidade de maneira parecida aos códigos de ética atuais. Em meio a tudo isso, durante os três séculos coloniais persiste a composição e edição de textos em línguas indígenas para apoio da evangelização, mas desde os últimos 25 anos do século XVI essas obras deviam ser revisadas por eruditos em língua indígena e doutrina cristã, que deviam constatar a correção do conteúdo e a propriedade da língua em que estava escrito. Falta dizer que houve diversas discussões em torno de algumas obras ou sobre a maneira de traduzir certos temas para determinados idiomas nativos.

\footnotetext{
9 Texto em espanhol: “Consulta sobre cuáles libros religiosos hay traducidos en lenguas indigenas y si los pueden tener los indios".

${ }^{10}$ Baseado na Recopilación de Leyes de los Reynos de las Indias mandadas recopilar por Carlos III en 1776, Madri, Conselho da Hispanidade, 1943.
} 
Essa maneira de estabelecer "traduções oficiais" —que são as que passaram para a posteridade - demonstra a imposição dos espanhóis neste âmbito, mas não significa que da parte dos indígenas não tivesse resistência. Seguramente, estas traduções foram produto de um processo de negociação entre espanhóis e indígenas onde os indígenas interviram ativamente, a julgar pela das Leis das Índias sobre que os intérpretes não deviam aceitar pagamentos extra dos índios e a especificação de eles deviam levar "um amigo cristão" (Lei XII) (isto é: alguém em que os espanhóis pudessem confiar) para assegurar que o intérprete não omitisse nem acrescentasse algo no que dizia o índio. Tudo no propósito de preservar a imparcialidade desse trabalho, nas palavras do Imperador D. Carlos e da Imperatriz Governadora em Valladolid em 12 de setembro de 1537:

Somos informados de que os Intérpretes e Nahuatlatos que têm as Audiências, e outros Juízes e Justiças das Cidades e Vilas de nossas Índias no tempo que os Índios os levam para outorgar escrituras, ou para dizer seus dizeres, ou fazer outros autos judiciais e extrajudiciais, e ouvir suas confissões, dizem algumas coisas, que não disseram os Índios, ou dizemnas e declaram-nas de outra forma, e assim muitos perderam sua justiça, e recebido grave dano: Mandamos que quando alguns dos Presidentes e Ouvintes de nossas Audiências, ou outro qualquer Juiz enviarei a chamar o Índio, ou Índios, que não saibam a língua Castelhana, para perguntar qualquer coisa, ou para qualquer efeito, ou vindo eles de sua própria vontade para pedir, ou seguir sua justiça, os deixem e consinta, que tragam consigo um Cristão amigo seu, que esteja presente, para que veja se o que eles dizem ao que é perguntando e pedem, é o mesmo que declaram os Nahuatlatos, e Intérpretes, não deixaram de declaram o que eles disseram, e se desculpem outros muitos inconvenientes, que se poderiam acrescentar ${ }^{11}$ (Grupo de Investigação 2007).

${ }^{11}$ Texto em espanhol: "Somos informados que los Intérpretes y Naguatlatos, que tienen las Audiencias, y otros Jueces y Justicias de las Ciudades y Villas de 
Em termos de ética de interpretação, isso já projeta os princípios dos códigos de ética de nossos tempos que, quase sempre, incluem: imparcialidade, neutralidade, confidencialidade, fidelidade à enunciação original e profissionalismo, embora se trate, no caso em questão, de uma atividade na qual convergem indígenas e missionários, com tudo o que implica a respectiva posição das partes na hierarquia política e linguística dentro da negociação.

\section{Dois exemplos de tradução e uma análise interdisciplinar}

Tendo em vista o que foi afirmado anteriormente, as estratégias de tradução empregadas para traduzir a doutrina cristã para a língua náhuatl não estão isentas de ambiguidades e, portanto, exigem análise multidisciplinar. Por razões de espaço, selecionamos somente dois exemplos de tradução retirados dos Coloquios de 1524, apresentamos o texto náhuatl e o texto em castelhano de da obra de Sahagún, além de uma tradução contemporânea, mais literal, pelo reconhecido nahuatlato Miguel León-Portilla (Sahagún 1986). O primeiro exemplo consiste na apresentação que os missionários fazem de seu Deus diante dos indígenas utilizando, para traduzir, algumas fórmulas linguísticas da língua para qual se traduz:

nuestras Indias al tiempo que los Indios los llevan para otorgar escrituras, ó para decir sus dichos, ó hacer otros autos judiciales y extrajudiciales, y tomarles sus confesiones, dicen algunas cosas, que no dixeron los Indios, ó las dicen $y$ declaran de otra forma, con que muchos han perdido su justicia, y recibido grave daño: Mandamos que quando algunos de los Presidentes y Oidores de nuestras Audiencias, ú otro qualquier Juez enviare á llamar á Indio, ó Indios, que no sepan la lengua Castellana, para les preguntar alguna cosa, ó para otro qualquier efecto, ó viniendo ellos de su voluntad á pedir, ó seguir su justicia, les dexen y consientan, que traygan consigo un Christiano amigo suyo, que esté presente, para que vea si lo que ellos dicen á lo que se les pregunta y piden, es lo mismo que declaran los Naguatlatos, é Intérpretes, porque de esta forma se pueda mejor saber la verdad de todo, y los Indios estén sin duda de que los Intérpretes no dexaron de declarar lo que ellos dixeron, y se excusen otros muchos inconvenientes, que se podrían recrecer".

Cad. Trad., Florianópolis, v. 41, n 1, p. 303-343, jan-abr, 2021. 


\section{Exemplo 1}

\begin{tabular}{|l|l|l|}
\hline Texto castelhano (83) & Texto náhuatl (124) & $\begin{array}{l}\text { Tradução de León- } \\
\text { Portilla (125) }\end{array}$ \\
\hline $\begin{array}{l}\text { El verdadero Dios } \\
\text { y universal, Señor, } \\
\text { criador dador del ser } \\
\text { y vida que os venimos } \\
\text { a predicar no es de la } \\
\text { condición de vuestros } \\
\text { dioses. }\end{array}$ & $\begin{array}{l}\text { Auh in iehoatzin, } \\
\text { tehtolli teutl } \\
\text { teiocoianj, in nelli nelli } \\
\text { ypalnemoanj, in nelli } \\
\text { tloque naoaque, in } \\
\text { tamechtiximachtilico } \\
\text { ca amo iuhcatzini... }\end{array}$ & $\begin{array}{l}\text { Pero aquél, que es } \\
\text { Dios verdadero, que } \\
\text { gobierna, verdadero } \\
\text { inventor de la } \\
\text { gente, el verdadero } \\
\text { Dador de la vida, el } \\
\text { verdadero Dueño del } \\
\text { cerca y del junto, } \\
\text { aquel que os venimos } \\
\text { a mostrar... }\end{array}$ \\
\hline
\end{tabular}

Fonte: (Sahagún 1986)

Notemos, aqui, que se cria um signo bicultural (Parodi 26). Diferentemente da adoção de palavras indígenas para o espanhol na qualidade de empréstimos linguísticos para se referir a conceitos ou objetos desconhecidos para os falantes da língua dos colonizadores, ou de outras classes de neologismo de contato (Otheguy and García 1993) que são resultado da relação entre línguas, o signo bicultural implica forçadamente uma ressemantização intencional. Embora poderia se considerar a cunhagem de um signo bicultural como algo "inocente", no caso dos nomes outorgados em espanhol (por exemplo, de frutas como abacaxi e de ervas como orégano devido à semelhança entre determinadas plantas europeias e mexicanas), a classe de neolexicalização envolvida nos signos biculturais nos exemplos tratados é uma manifestação evidente de um processo intencionado, de um impulso para a mudança linguística, uma imposição cultural que tem, como propósito, erradicar uma forma de pensar e substituir um sistema de crenças.

Aprecia-se uma tentativa de negociação por parte dos evangelizadores que buscam utilizar para seu próprio benefício conceitos já existentes em náhuatl com a anteposição do vocábulo nelli, que significa "verdadeiro". No entanto, seria possível afirmar que a negociação fracassa quando os nahuas não reconhecem aos "ver- 
dadeiros" deuses deste novo discurso como senão seus próprios e tradicionais deuses, seus verdadeiros deuses, o que pode ser apreciado mais claramente no seguinte quadro onde se separa o vocabulário do exemplo anterior:

Tabela 1: Vocabulário pré-hispânico cristão em castelhano

\begin{tabular}{|l|l|}
\hline $\begin{array}{l}\text { Significado pré-hispânico em } \\
\text { castelhano }\end{array}$ & Significado cristão em castelhano \\
\hline $\begin{array}{l}\text { teutl }=\text { dios, divinidad, inminente } \\
\text { en bien y en mal, muerto... }\end{array}$ & nelli teutl = "verdadero dios" \\
\hline $\begin{array}{l}\text { tlahtoanj = lit. que tiene la } \\
\text { palabra. Quien gobierna }\end{array}$ & $\begin{array}{l}\text { nelli teutl tlahtoanj = "verdadero } \\
\text { Dios universal" }\end{array}$ \\
\hline $\begin{array}{l}\text { teiocoianj = inventor de la } \\
\text { gente" (dios azteca Quetzalcóatl) }\end{array}$ & $\begin{array}{l}\text { nelli teiocoianj = "verdadero } \\
\text { Creador" }\end{array}$ \\
\hline $\begin{array}{l}\text { ypalnemoanj = "aquel por quien } \\
\text { se vive" (dios azteca Tezcatlipoca) }\end{array}$ & $\begin{array}{l}\text { nelli ypalnemoanj }=\text { "verdadero } \\
\text { Dador del ser y la vida" }\end{array}$ \\
\hline $\begin{array}{l}\text { tloque naoaque = "Dueño del } \\
\text { cerca y del junto" (divinidad } \\
\text { abstracta que posee todo y da } \\
\text { verdad, cimiento, a todo cuanto } \\
\text { existe). }\end{array}$ & $\begin{array}{l}\text { nelli tloque naoaque = Sin } \\
\text { traducción en el texto castellano. }\end{array}$ \\
\hline
\end{tabular}

Fonte: As autoras

Apresentamos outro exemplo de narração dos franciscanos, sobre a rebelião dos anjos e a soberba de Lúcifer, onde a estratégia é conservar palavras em castelhano na tradução para o náhuatl e usar algumas expressões deste idioma em seu sentido original:

\section{Exemplo 2}

\begin{tabular}{|l|l|l|}
\hline Texto castelhano (92) & Texto náhuatl (170) & $\begin{array}{l}\text { Tradução de León- } \\
\text { Portilla (171 }\end{array}$ \\
\hline $\begin{array}{l}\text { Es de saber que entre } \\
\text { aquellos } \text { príncipes }\end{array}$ & $\begin{array}{l}\text { Auh ce iehoati in vel } \\
\text { intiachcauh catca }\end{array}$ & $\begin{array}{l}\text { Pero uno de ellos el } \\
\text { que era mayor, }\end{array}$ \\
\hline
\end{tabular}

Cad. Trad., Florianópolis, v. 41, no 1, p. 303-343, jan-abr, 2021. 


\begin{tabular}{|c|c|c|}
\hline $\begin{array}{l}\text { cavalleros que nuestro } \\
\text { Señor Dios crió, fue uno } \\
\text { más principal, excelente y } \\
\text { generoso que todos los } \\
\text { otros, muy iminente en } \\
\text { hermosura y sabiduría } \\
\text { (el qual se llamaba } \\
\text { Luzifer). Este supremo } \\
\text { príncipe, como se } \\
\text { vio ser más excelente } \\
\text { que todos los demás } \\
\text { príncipes, leuantose en } \\
\text { soberuia y presunción; } \\
\text { quiso valer más que } \\
\text { todos y dixo en su } \\
\text { coraçon: pondré mi } \\
\text { trono junto del todo } \\
\text { poderoso Dios, subiré } \\
\text { y seré semejante a él, y } \\
\text { muchos príncipes fueron } \\
\text { deste voto y parecer... }\end{array}$ & $\begin{array}{l}\text { inqujceiacanaia } \\
\text { in qujpanaviaia } \\
\text { chipavaliztica } \\
\text { chicaualzitica, yoa } \\
\text { tlamatiliztica (ytoca } \\
\text { Lucifer) yn iquac } \\
\text { omottac in qnin } \\
\text { cenca qujpanavia in } \\
\text { ixquichtni angeles, yc } \\
\text { omopouh yc oatlama } \\
\text { omotachcauhnec, } \\
\text { oquito Nicneneviliz in } \\
\text { tlacempanavia Dios yn } \\
\text { ipalnemoanj, yn nopetl } \\
\text { yn nocpal intla nictecaz } \\
\text { in jpetlatzin in jcpaltzin } \\
\text { tineneuhq tiezque } \\
\text { noconaciz... }\end{array}$ & $\begin{array}{l}\text { que estaba al frente } \\
\text { de los otros, que } \\
\text { los sobrepasaba en } \\
\text { hermosura, en fuerza y } \\
\text { sabidurí, (el nombre } \\
\text { de este era Lucifer), } \\
\text { cuando vio cómo } \\
\text { mucho sobrepasaba } \\
\text { a los otros ángeles, } \\
\text { entonces con esto se } \\
\text { estimó en mucho, no } \\
\text { tuvo medida, quiso aún } \\
\text { ser más, } \\
\text { dijo: - Yo seré igual } \\
\text { a Dios que está por } \\
\text { encima de todo, el } \\
\text { Dador de la vida. Mi } \\
\text { estera, mi sitial, si yo } \\
\text { los coloco al lado de } \\
\text { su estera, su sitial, } \\
\text { seremos iguales. Yo } \\
\text { habré de } \\
\text { alcanzarlo. Y } \\
\text { conjuntamente muy } \\
\text { muchos se pusieron de } \\
\text { su lado, de su voluntad } \\
\text { lo escucharon, lo } \\
\text { honraron, vieron bien } \\
\text { su palabra, lo hicieron } \\
\text { su señor... }\end{array}$ \\
\hline
\end{tabular}

Fonte: (Sahagún 1986)

Além das palavras castelhanas "Lucifer", "angeles" e "dios" no texto em náhuatl, temos a fórmula náhuatl "jpetlatzin in jcpaltzin", que denota autoridade, pois refere-se ao lugar de mando em náhuatl: "la estera, el sitial", o trono. Notamos que, aqui, ipalnemoanj se refere ao deus cristão, mas no lugar do vocábulo nelli, como nos exemplos anteriores, está acompanhado da palavra "deus". 
A primeira coisa que se sobressai nesses fragmentos é a postura colonialista e eurocêntrica: os missionários não têm a menor dúvida de que eles conhecem a verdade, têm a verdadeira religião e irão ensiná-la aos indígenas para que eles possam reconhecer que suas antigas crenças eram erros ocasionados pela falta de conhecimento da religião cristã. Trata-se de uma relação assimétrica de vencedor-vencido, da qual o missionário assume que há uma relação de verdade-falsidade entre seu próprio discurso e o dos índios, o que faz com que o intercâmbio cultural se torne, às vezes, violento (alguns indígenas foram mortos) e, em geral, impositivo: a proposta é impor o evangelho a aqueles que não só desconhecem, mas a aqueles - assim se considerava- que estão equivocados com respeito ao mundo. É por isso que a imposição da fé e a destruição do indígena é assumida pelos missionários como um dever ético para favorecer os nativos.

Os religiosos querem expor seu próprio pensamento e impor sua verdade ao indígena, mas sabem que não podem fazer isso sem se aproximar deles, sem retomar suas palavras ou condescender com alguns elementos culturais (como o uso de "jpetlatzin in jcpaltzin" em seu sentido original em castelhano: "la estera, el sitial", que significa autoridade) e, sobretudo, sem negociar linguisticamente para favorecer a recepção da mensagem evangélica. Os missionários sabem que certas fórmulas se referem às divindades indígenas. Eles mesmos provaram que Ypalnemoanj era o deus Tezcatlipoca e que Tloque Naoaque era uma fórmula que se referia, de maneira abstrata, à divindade. $\mathrm{O}$ fato de que essas duas expressões em náhuatl são as mais empregadas nos discursos de evangelização deve ser entendido como uma estratégia mediante a qual os missionários buscaram aproximar o conceito cristão "deus" dos indígenas. É como se os evangelizadores quisessem dizer a eles: "temos um ser que é como teutl (em náhuatl, deus) ou Ypalnemoanj de vocês", mas no afã necessário de diferenciar entre as concepções nahuas e cristãs e de evitar confusão de ambos os conceitos, e para deixar claro tanto a novidade da mensagem evangélica como a superioridade de compor frases novas de acordo com a mensagem 
cristã e suas intenções evangélicas: nelli teutl tlatuani, um teutl verdadeiro que é superior aos demais, o teutl que governa e possui a palavra, opondo assim o teutl indígena ao nelli teutl dos cristãos.

Surge, assim, um tema fundamental, que é o da compreensão intercultural. Não se trata somente de que uma mensagem possa ser expressada em dois idiomas distintos, mas sim de que seu sentido e significado sejam compartilhados. A incomensurabilidade cultural faz-se patente nas indagações dos religiosos sobre o mundo pré-hispânico, como quando Sahagún adverte sobre as superstições e cerimônias idolátricas que os indígenas praticavam sem que os cristãos percebessem, e assim "os confessores nem se perguntavam nem pensavam que tal coisa existe, nem sabem a linguagem para perguntar, nem mesmo entendem ainda que eles dissessem"12 (Sahagún 15). Dificilmente é possível separar linguagem e pensamento, e são muitos os estudos que exploram os terrenos da língua, da cultura e da visão de mundo, que vão desde as indagações pioneiras de Condillac e Humboldt nos séculos XVII e XIX, passando pelas investigações dos linguistas antropólogos Boas, Sapir e Whorf nas primeiras décadas do século XIX, com suas hipóteses em torno do determinismo e da relatividade linguística, até às considerações atuais dentro da linguística cultural e cognitiva (Ávila 1992; Everett 2005; Palmer 1996 and Wierzbicka 2013, 2015).

Seria imprudente, condescendente e até desdenhoso adotar um determinismo extremo, já que se leva ao exagero que "o determinismo linguístico implica que o homem não poderia imaginar um tipo de conhecimento que não estivesse codificado por sua língua" e havia que se considerar uma postura mais aberta, dado que "deve-se refletir que, se não se dispõe de uma palavra determinada para expressar uma ideia, pode haver recursos gramaticais que sim permitam ou, inclusive, os falantes possam adquirir esse conceito, por exemplo, a partir dos empréstimos linguísticos”, como já

\footnotetext{
${ }^{12}$ Texto em espanhol: "los confesores ni se las preguntan ni piensan que hay tal cosa, ni saben lenguaje para se lo preguntar, ni aun lo entenderán, aunque se lo digan".
}

Cad. Trad., Florianópolis, v. 41, n 1, p. 303-343, jan-abr, 2021. 
notamos, porque eles "representam a possibilidade de entender a realidade mediante um código linguístico distinto" ${ }^{13}$ (Muñoz 36)

No entanto, no começo dessa história, e como apontamos quando falamos do caso da tradução radical de Quine (1968), pode haver mal-entendidos no emprego de imagens e sinais para se comunicar e para aprender a língua do outro, pois cada povo atende a percepções distintas quando observam e mostram, respectivamente e, para nosso caso, os quadros da virgem ou de qualquer outro santo, de tal maneira que os indígenas consideravam "Santa Maria" como equivalente a "imagem", usando o nome do representado para denominar a representação como uma espécie de ampliação do significado, se nos utilizamos dos termos da linguística.

Isso repercute diretamente no estabelecimento de equivalentes linguísticos em palavras como teutl e dios, pois teutl é uma noção mais ampla que deus uma vez que se aplica também aos mortos e ao que iminentemente é bom ou ruim, o que também nos remete a noções diversas de divindade, em termos culturais, e que a linguística trataria como uma relação de hiperonímia: "deus" é um hipônimo do hiperônimo "teutl". Mas, inclusive quando duas frases são literalmente equivalentes, como teiocoianj e "inventor de gente", podem surgir ambiguidades devido a que cada uma delas se relaciona com entidades distintas dentro de cada cosmovisão: teiocoianj refere-se à divindade Quetzalcóatl para os nahuas, e para os cristãos nomeia seu deus como criador. Sem significados compartilhados, ainda com o uso das mesmas expressões, estamos diante de um signo bicultural onde cada um entende essas palavras à sua maneira. Somente na medida em que fosse imposto um dos significados, ou fosse criado um novo, poderíamos dizer que existe um significado compartilhado, o que é um tipo de mudança linguística, mas nos introduz também no dilema de se a tradução é fiel ao original.

13 Texto em espanhol: "representan la posibilidad de entender la realidad mediante un código lingüístico distinto". 
Geralmente, assume-se que o indígena foi inculturado, pois ao ser vencido e subjugado, não teve outra opção a não ser receber e aceitar tudo o que os vencedores impuseram. Assim, sua negligência para aceitar a fé ou sua conversão fingida foi tratada como parte da problemática sobre a racionalidade do índio. No entanto, diante do afirmado, é obrigatório se perguntar em que medida é possível evadir da imposição religiosa e cultural mediante a tradução se ela ajudou, de alguma forma, a que o indígena pudesse escolher o que aceitava - e fosse aculturado- daqueles que repetiam uma e outra vez, ainda que de maneira estranha, essas frases nas quais ainda se ressoava sua cosmovisão. Em termos de inculturação, deveríamos falar de fidelidade da tradução a um texto original, mas em referência às obras linguístico-doutrinais novo hispânicas, em geral, não existe um original (Payàs 82): no lugar temos obras doutrinais, bilíngues ou trilíngues, que se traduzem entre si ou, melhor dizendo, que traduzem a mensagem cristã para as línguas americanas. A fidelidade que se buscaria neste caso é doutrinal, teológica, e ainda mais se lembramos que a tradução de textos religiosos cristãos para diferentes idiomas foi um assunto muito discutido na Europa desde antes da descoberta da América, que foi uma das polêmicas fundamentais contra os diferentes movimentos da reforma e que se resolveram, desde a Igreja Católica, na sessão IV de 8 de abril de 1546 (Denzinger 279-281), quando o Concílio de Trento estabeleceu que a versão autêntica da Bíblia era a chamada Vulgata. Além disso, foi decretado que ninguém deveria interpretar a Sagrada Escritura de forma contrária ao sentido dado pela Igreja de Roma, e foram estabelecidas várias restrições para poder publicar e editar a Bíblia e qualquer livro sobre assuntos sagrados. Por isso, como antes afirmamos, a tradução da doutrina cristã para a língua náhuatl é intralinguística ao mesmo tempo que é interlinguística.

Contudo, ainda quando se tratasse de inculturação, é necessário que o que foi falado seja compartilhado, que a coisa dita pelo emissor seja compreendida em seu significado original por quem ouve, que a língua para qual se traduz não se mantenha alheia à nova mensagem que nela se expressa, e que o destinatário receba 
o discurso no sentido em que foi emitido. Aqui entrariam todas as emendas, correções e acréscimos que os colegiais de Tlatelolco faziam nos discursos dos freis, e certamente também o resultado de inúmeras discussões entre os indígenas, e deles com os religiosos, sobre as melhores maneiras de traduzir alguns conceitos fundamentais. Quanta resistência a língua náhuatl opôs à expressão unilateral da doutrina cristã? Talvez a mesma que os indígenas opuseram, particularmente aos receptores do discurso de evangelização que não foram educados nos conventos, os quais poderiam entender ou não - aceitar ou não- o que os freis quiseram dizer no sentido que quiseram dizer. $\mathrm{O}$ conceito aculturação aparece, aqui, como um termo mais adequado que o de inculturação para denominar a interação cultural.

Com relação ao objetivo da tradução por parte dos missionários, devemos dizer que a linguagem é violentada porque são os freis que desejam expressar sua mensagem e serem compreendidos e aceitos pelos indígenas, que por sua vez direcionam as traduções para evangelizar decidindo o que as palavras nativas deveriam significar e a maneira em que os indígenas deveriam entender suas próprias e antigas frases: outorgando um significado cristão às fórmulas linguísticas que originalmente designam uma cosmovisão muito distinta, e propondo destruir ou fazer esquecer esse significado ao implementar uma nova religiosidade mediante a criação de um discurso cristão náhuatl padronizado e favorável a seus interesses. O náhuatl é forçado a adquirir um significado cristão fazendo precisões com acréscimos como nelli ou com a criação de frases novas como nelli tloque naoaque, mas também mediante a introdução de palavras castelhanas -Lúcifer, anjos, Deus- nos discursos nahuas, com as quais se introduzem novos conceitos e entidades com suas respectivas associações culturais, ou mediante o que se conhece como práticas domesticadoras, redução etnocentrista de conceitos, ressemantizações e tentativas de obliteração da cosmovisão nahua.

É provável que não houvesse diferença entre Ypalnemouanj e nelli Ypalnemouanj para os indígenas, salvo talvez a estranheza 
diante de uma fórmula que não era usual antes da chegada dos cristãos. A distinção entre uma e outra está na intenção dos missionários, para os quais o "dador da vida" dos mexicas era um usurpador do "verdadeiro dador da vida" que eles vinham pregar. Tal distinção talvez também foi clara para os indígenas que, junto com os freis, de alguma maneira entraram em acordo para a conveniência do emprego de tais palavras como equivalentes em ambos idiomas ou a utilidade de determinadas frases como a melhor maneira de pregar sobre o deus cristão em um discurso onde a semântica e a pragmática lutam entre si. Infelizmente, é difícil determinar a forma com a qual puderam realizar esses acordos e os argumentos que defenderam em cada situação.

Em qualquer caso, é pertinente lembrar da hermenêutica gadameriana porque propõe que a compreensão se constrói com o diálogo em uma espécie de jogo no qual ambos os interlocutores buscam entender-se. Entretanto, isso não deve ser entendido como o fato de compreender o que "o outro quis dizer", mas sim como o ir e vir na linguagem, no diálogo onde cada um se faz valer diante do outro para coincidir, finalmente, "no que diz a palavra" (Gadamer 461). Não se trataria, portanto, de uma tradução fiel à uma mensagem original, mas sim de alcançar uma mensagem "intermediária", um discurso compartilhado onde possam coincidir missionário e indígena, onde apesar de predominar a mensagem cristã, por seu conteúdo, ela se vê afetada pelo receptor indígena e sua língua que se negam a apagar a tradição de suas palavras, que buscam a acomodação para as palavras de outro idioma entre o que já acreditavam e possuíam e que, inclusive involuntária e inconscientemente, subvertem a mensagem cristã para ao igualar deus com tloque naoaque porque, de fato, "as línguas não se diferenciam pelo que podem dizer - em geral são traduzíveis umas para as outras -, mas sim pelo que não podem deixar de dizer" ${ }^{14}$ (Ávila 12).

${ }^{14}$ Texto em espanhol: "las lenguas no se diferencian por lo que pueden decir -en general son traducibles unas a otras- sino por lo que no pueden dejar de decir".

Cad. Trad., Florianópolis, v. 41, ${ }^{0}{ }^{1}$, p. 303-343, jan-abr, 2021. 
Se é esse o caso, devemos abandonar todo o eurocentrismo e postura colonialista, e assumir que os "desentendimentos" seriam as "más traduções" que não foram advertidas pelos freis. Desde o ponto de vista funcionalista, devemos distinguir entre erros linguísticos, que são erros gramaticais, erros de léxico, erros de ortografia e de pontuação, e erros de tradução, os quais podem ser erros pragmáticos ou culturais. Em termos gerais, se o propósito de uma tradução é o de alcançar uma função particular para o destinatário, tudo o que impeça atingir esse propósito é um erro de tradução (Nord 1996, 1997). Em nosso caso, as "más traduções" são as que falham em erros pragmáticos e culturais. As más traduções da doutrina cristã não seriam, desde essa perspectiva, as que discrepam da ortodoxia ou de algum texto original, mas sim as que não conseguiram apagar os significados pré-hispânicos dos discursos de evangelização e as que, pelas características gramaticais das línguas envolvidas, não conseguiram expressar de maneira clara e unilateral a mensagem cristã. A correção de uma tradução depende, nessa situação, não da fidelidade a um original, mas sim que seria relativa ao missionário, para quem era adequado nomear Ypalnemouanj a seu deus, e relativa ao indígena que pode acrescentar, graças a essas decisões na tradução. Embora talvez, com o tempo, com o contato cultural prolongado e pelo mesmo desenvolvimento histórico da língua, ambas as concepções se fundiram em uma terceira que as conjugava de alguma maneira: a hibridez.

Esta combinação heterogênea como base da conceitualização tradutológica acompanha o desenvolvimento teórico da tradução da mesma maneira que a linguística missionária também acompanha, como afirmamos anteriormente. Por conseguinte, nossa postura não seria concebível sem antecedentes tradutológicos e sem a re-conceitualização do ato da tradução ocorridos durante o último meio século. Hoje, parece-nos evidente que a tradução é uma atividade culturalmente situada graças ao trabalho de Bassnett e Lefevere (1990), os quais não só ressaltaram o terreno comum entre a literatura comparada e a tradutologia, mas também aqueles que foram os primeiros em sugerir que fosse reposicionado o foco da 
investigação para retirá-lo do eurocentrismo. No mesmo marco do argumento pós-colonial, pós-estruturalista e pós-moderno (Cronin 2000; Gentzler 2008), o tradutor deveria se fazer presente mediante a resistência diante das expectativas, como propõe Venuti (2008) em sua campanha pela visibilidade do tradutor no princípio do novo milênio, o que se realiza através do ativismo (Tymoczko 1999, 2010) a nível microtextual, com cujos atos de resistência, no entanto, se desafia às narrativas dominantes (Baker 2006) a nível macrotextual. Enfim, a interpretação final da tradução oficial dos Coloquios de 1524 pertence à comunidade indígena, e apesar de todo seu poder, os evangelizadores e os colonizadores não tinham a última palavra para decidir o significado dos sinais e das expressões cujos significantes tentaram definir.

\section{Considerações Finais}

A tradução da doutrina cristã para a língua náhuatl forma parte de um fenômeno sumamente complexo desde seu próprio acontecimento: a concorrência de indígenas (idosos não cristianizados e meninos educados pelos freis) e missionários na composição de textos para evangelizar, o fato de que essa atividade fosse simultânea à aprendizagem do náhuatl pelos missionários e do latim e do castelhano pelos indígenas, aos quais se acrescentam as demais atividades que os religiosos realizaram para efetuar seu trabalho na nascente sociedade colonial. Tudo isso obriga a que esse estudo tenha que atender, também de maneira simultânea, a aspectos distintos que surgiram ou repercutiram nesse exercício de interpretação e realização da tradução desde um trabalho interdisciplinar cujas conclusões oscilarão entre a tradutologia e outras disciplinas que, como mostramos, muitas vezes deverão repropor suas categorias tradicionais ou suas questões fundamentais.

A negociação linguística materializa-se, no caso analisado, tanto nas diferentes estratégias de tradução e na conformação de um vocabulário cristão em náhuatl, como nos diferentes resultados da 
própria interação entre indígenas e missionários: mal-entendidos, compreensão de um discurso sem aceitação, "más traduções", hibridez e surgimento de novas formas de identidade. Questões como essas obrigam a perguntar-se se, realmente, a tradução da doutrina cristã foi unilateral, se a intervenção dos indígenas ocasionou que se conservasse mais do que era pré-hispânico do que os freis podiam advertir e tolerar, e se a causa da própria natureza da tradução, especialmente pelos idiomas envolvidos, não estamos senão diante do surgimento de novos significados produzidos pela conjunção da mensagem cristã, da língua náhuatl e do trabalho conjunto de indígenas e missionários na interpretação e tradução. Em todo caso, nos exemplos analisados revela-se a mentalidade colonialista apesar de que a violência dos instigadores da tradução (e da situação assimétrica predominante) não podia prescindir de uma negociação linguística que considerasse tanto as questões semânticas, sintáticas e pragmáticas quanto as culturais (a diferença de cosmovisões), políticas (colonialismo) e, inclusive, religiosas (tanto as europeias quanto as pré-hispânicas).

Os missionários atuaram como agentes para a mudança, uma mudança que aconteceu entre diferentes espaços e grupos sociais, entre colonizadores e colonizados, e que culminou em um processo de transformação cultural (Castillo-Rodriguez 78). No caso da Nova Espanha, essa transformação foi introduzida na interrelação entre nahuas e missionários (entre outros agentes coloniais) e apresentaram como resultado uma alteração linguística por meio de uma série de empréstimos, calcos que deviam ser incorporados no náhuatl com o impacto da ressemantizações, mas que resultaram em mudanças tanto na língua colonizada como do colonizador, além de possíveis atos de catacreses e prováveis heresias. Parece que, em termos de tradutologia, dentro de nossa compreensão atual, a resposta à conceitualização das atividades encontra-se em considerar a teoria da complexidade - mais que multidisciplinar, interdisciplinar-, que não provem dos centros tradicionais do pensamento eurocêntrico, mas sim da periferia dos impérios coloniais levando em consideração que, na tradução, como todo encontro 
cultural, estão envolvidos, pelo menos, dois povos distintos, cada um com sua própria língua e cosmovisão, mas também cada um com algo para contribuir e receber, apesar de um deles pretenda impor-se sobre o outro, pela simples razão de que o vencido não é passivo e as línguas também resistem à transformação.

\section{Referências}

Anchondo Pavón, S. La persuasión del bien y la palabra. Retórica y filosofía moral en fray Bernardino de Sahagún. México: Universidad Panamericana/ Porrúa Print, 2014.

Antonini, R. (Ed.). "Child language brokering: Trends and patterns in current research. Mediazioni”. Rivista Online di Studi Interdisciplinari su Lingue e Culture, 10 (2010). < http://www.mediazioni.sitlec.unibo.it/index.php/no-10special-issue-2010.html > .

Ávila, R. Lengua y cultura. México: Trillas, 1992.

AIIC. Interpreting is not translating, 2012. < http://aiic.net/p/4002>

Baker, M. (2006). Translation and conflict: A narrative account. Londres: Routledge, 2006.

Bassnett, S.; Lefevere, A. Translation, history and culture. Londres, Reino Unido: Printer Publishers, 1990.

Bastin, G. "Por una historia de la traducción en Hispanoamérica". Íkala, Revista de Lenguaje y Cultura, 8.14 (2003): 193-217. 
Beuchot, M. Filosofía social de los pensadores novohispanos. México: Instituto Mexicano de Doctrina Social y Cristiana, 1990.

Burke P. e Po-Chia Hsia, R. Cultural translation in early modern Europe. Cambridge: Cambridge University Press, 2007.

Castillo-Rodríguez, S. "The first missionary linguistics in Fernando Po". Colonialism and missionary linguistics, K. Zimmerman y B. Kellermeier-Rehbein (Eds.), Berlín, Alemania: De Gruyter, 2015. pp. 75-106.

Chesterman, A. "Interpreting the meaning of translation". A man of measure: Festschrift in honour of Fred Karlsson on his $60^{\text {th }}$ birthday, A. Suominen (Ed.), Turku, Finlandia: Linguistic Association of Finland, 2006. pp. 3-11.

Chiodi, F.; Loncón, E. Crear nuevas palabras. Innovación y expansión de los recursos lexicales de la lengua mapuche. Temuco, Chile: Instituto de Estudios Indígenas/CONADI, 1999. 22/04/2020. < http://cayu.com.ar/files/neologismosmapuche.pdf $>$.

Cronin, M. "History, translation, postcolonialism". Changing the terms: Translating in the postcolonial era, S. Simon y P. St-Pierre (Eds.),. Ottawa, Canadá: University of Ottawa Press, 2000. pp. 33-52.

Cuesta, de la, L.A. "Intérpretes y traductores en el descubrimiento y conquista del nuevo mundo". Livius, 1, (1992): 25-34. 22/04/2020 < https://buleria.unileon. es/xmlui/handle/10612/6323>.

D'amore, A.M., Murillo Gallegos, V. e Zimányi, K. "Have faith in your vocabulary. The role of the interpreter in the conquest of power, language and ideology in the New Spain”. Linguistica Antverpiensia, New Series: Themes in Translation Studies, 15, (2016): 36-50. 22/04/2020. < https://lans-tts. uantwerpen.be/index.php/LANS-TTS/article/view/393> .

Denzinger, H. Enchiridium simbolorum. Barcelona, España: Herder, 1948.

European Commission. Translation and interpreting: Languages in action. Luxemburgo: European Communities, 2009. 
Everett, D.L. "Cultural constraints on grammar and cognition in Pirahã: Another look at the design features of human language". Current Antropology, 46.4, (2005): 620-646. 22/04/2020. < https://www1.icsi.berkeley.edu/ kay/Everett. CA.Piraha.pdf $>$.

Faulstich Orellana, M. Translating childhoods: Immigrant youth, language and culture. New Brunswick, NJ: Rutgers University Press, 2009.

Fernández del Castillo, F. (comp.). Libros y libreros en el siglo XVI. México: Fondo de Cultura Económica, 1982.

Frost, E. C. Este nuevo orbe. México: Centro Coordinador de Estudios Latinoamericanos, Universidad Nacional Autónoma de México, 1996.

Frost, E. C. La historia de dios en las Indias, visión franciscana del Nuevo Mundo. México: Tusquets, 2002.

Gadamer, H. G. Verdad y método 9a ed., Salamanca, España: Ediciones Sígueme, 2001.

Gentzler, E. Translation and identity in the Americas. New directions in translation theory. Londres, Reino Unido / Nueva York, NY: Routledge, 2008.

Grupo de investigación. T-1611. "De los intérpretes. Leyes de Indias. Libro ii, título xxix". 1611, Revista de Historia de la Traducción, 1.1, (2007). 22/04/2020. $<$ http://www.traduccionliteraria.org/1611/esc/america/leyes.htm > .

Harris, B. The importance of natural translation. Working papers in bilingualism, 12, (1976): 96-114. 22/04/2020. <https://www.academia.edu/1406388/The importance_of_natural_translation $>$.

Harris, B. An annotated chronological bibliography of natural translation with native translation and language brokering, 1913-2012. 22/04/2020. < https:// www.academia.edu/5855596/Bibliography_of_natural_translation > .

Hokkanen, S. \& Downie, J. Panel 21. Mediators of the divine: Rethinking the concept of 'interpreter' in light of interpreting in religious contexts. En 8th EST Congress 2016. Panel efectuado el 17 de septiembre en Aarhus, Dinamarca, 2016. 
Hurtado Albir, A. Traducción y traductología. Introducción a la traductología $7^{\text {a }}$ ed., Madrid: Cátedra, 2014.

Hurtado Albir, A (Ed.). Researching translation competence by PACTE Group. Amsterdam, Holanda: John Benjamins Publishing Company, 2017.

Icíar, A., Baigorri, J. e Payàs, G. Nahuatlatos y familias de intérpretes en el México colonial. Revista 1611 de Historia de la Traducción, 2.2 (2008). 22/04/2020 < http://www.traduccionliteraria.org/1611/art/alonso-baigorripayas.htm $>$.

Koerner, E.F.K. “Koerner's korner”. Historiographia Linguistica, 36.2/3, (2009): 481-488.

Interpreters' Guild of America. 22/04/2020. < http://www.interpretersguild.org > .

Jakobson, R. "On linguistic aspects of translation". On translation, R. A. Bower (Ed.), Cambridge, MA: Harvard University Press, 1959. pp. 232-239.

Martinez, C. R.; McClure, H. H. \& Eddy, J. M. "Language brokering contexts and behavioral and emotional adjustment among Latino parents and adolescents". The Journal of Early Adolescence, 29.1, (2009): 71-98. 22/04/2020 . < https:// www.ncbi.nlm.nih.gov/pmc/articles/PMC2630236/>.

Mendieta, Fr. G. de. Historia eclesiástica indiana. México, D.F., México: Consejo Nacional para la Cultura y las Artes, 1997.

Morales, A.; W.E. Hanson. "Language brokering: An integrative review of the literature”. Hispanic Journal of Behavioral Sciences, 27 (2005): 471-503.

Motolinía, Fr. T. Memoriales, libro de las cosas de la Nueva España y de los naturales de ella. México: Instituto de Investigaciones Históricas, Universidad Nacional Autónoma de México, 1971.

Muñoz, M. El léxico disponible en dos regiones de Zacatecas. Una lectura a partir de la memética, la teoría de la evolución cultural. Zacatecas, México: Universidad Autónoma de Zacatecas/Taberna Libraria Editores, 2014. 
Murillo Gallegos, V. Palabras de evangelización, problemas de traducción. Fray Juan Bautista de Viseo y sus textos para confesores, Nueva España (siglo XVI). Zacatecas, México: Coordinación de Investigación y Posgrado, Universidad Autónoma de Zacatecas, 2009.

NAATI. 22/04/2020. < https://www.naati.com.au >.

Nord, C. "El error en la traducción. Categorías y evaluación”. Estudios sobre la traducción, A. Hurtado Albir (Ed.), Castelló, España: Universitat Jaume I. 1997, pp. 91-107.

Nord, C. Translating as a purposeful activity. Functionalist approaches explained. Manchester, Reino Unido: St. Jerome, 1996.

Olmos, Fr. A. de. Arte de la lengua mexicana. México: Universidad Nacional Autónoma de México, 2002.

Otheguy, R. \& García, O. "Convergent conceptualizations as predictors of degree of contact in U.S. Spanish". Spanish in the United States: linguistic contact and diversity. A. Roca y J.M Lipski (Eds.), Berlin y Nueva York: Mouton de Gruyter, 1993, pp, 135-154.

PACTE. 22/04/2020. < http://grupsderecerca.uab.cat/pacte>.

Palmer, G.B. Toward a theory of cultural linguistics. Austin, TX: University of Texas Press, 1996.

Parodi, C. "La semántica cultural: un modelo de contacto lingüístico y Las Casas". Visiones del encuentro de dos mundos en América. Lengua, cultura, traducción y transculturación, K. Dakin, M. Montes de Oca y C. Parodi (Eds.), México / Los Ángeles, CA: Universidad Nacional Autónoma de México/Universidad de California en los Ángeles-Centro de Estudios Coloniales Iberoamericanos, 2009, pp. 19-45.

Payàs Puigarnau, G. El revés del tapiz. Traducción y discurso de identidad en la Nueva España (1521-1821). Madrid, España: Iberoamericana Vervuert, 2010. 
Payàs Puigarnau, G. \& Zavala, J. M. La mediación lingüístico-cultural en tiempos de guerra: cruce de miradas desde España y América. Temuco, Chile: Universidad Católica de Temuco, 2012.

Payàs Puigarnau, G.; Zavala, J. M.; Samaniego, M. \& Garbarini, C. G. (2009). "Aproximación interdisciplinar a la mediación lingüística mapudungun-castellano ss. XVII-XIX: traductología, antropología histórica, filosofía”. Mutatis Mutandis. 2.1, (2009): 85-97. Sistema de revistas da Universidad de Antioquia. 22/04/2020. $<$ https://aprendeenlinea.udea.edu.co/revistas/index.php/mutatismutandis/ article/view/1826/1663>.

Phelan, M. e Martín, M. "Interpreters and cultural mediators-different but complementary roles". Translocations. 6.1, (2010): 1-72. 22/04/2020 <http:// doras.dcu.ie/16481/1/Martin_and_Phelan_Translocations.pdf > .

Pöchhacker, F. "Interpreting as mediation". Crossing borders in community interpreting: definitions and dilemmas, C. Valero Garcés y A. Martin (Eds.), Amsterdam, Holanda / Philadelphia, PA: John Benjamins Publishing Company, 2008, pp. 9-26.

Quine, W.V. Palabra y objeto. Barcelona, España: Labor, 1968.

Ricard, R. La conquista espiritual de México. Ensayo sobre el apostolado y los métodos misioneros de las órdenes mendicantes en la Nueva España de 1523 a 1572. México: Fondo de Cultura Económica, 1986.

Ríos Castaño, V. Translation as conquest. Sahagún and Universal History of the Things of New Spain. Madrid, España: Iberoamericana Vervuert, 2014.

Ríos Reyes, M. El teatro como recurso evangelizador: Sincretismo cultural [tesis inédita de Licenciada en Filosofía]. México: Universidad Nacional Autónoma de México, 2016.

Rovira Gaspar, M. del C. Francisco de Vitoria. España y América. El poder y el hombre. México: Miguel Ángel Porrúa / H. Cámara de Diputados, LIX Legislatura, 2004. 
Rudvin, M. \& Spinzi, C. G. "Negotiating the terminological borders of 'language mediation' in English and Italian. A discussion on the repercussions of terminology on the practice, self-perception and role of language mediators in Italy”. Lingua Culture Mediazioni/Languages Culture Mediation, 1.1-2, (2015): 57-79. 22/04/2020< https://www.ledonline.it/index.php/LCM-Journal/article/ view $/ 748>$.

Sahagún, Fr. B. de. Coloquios y doctrina cristiana, con que los doce frailes de San Francisco enviados por el papa Adriano Sexto y por el emperador Carlos Quinto: convirtieron a los indios de la Nueva España en Lengua Mexicana y española. México: Instituto de Investigaciones Históricas, Universidad Nacional Autónoma de México, 1986.

Sahagún, Fray B. de. Historia general de las cosas de la Nueva España, $11^{\mathrm{a}}$ ed., México: Porrúa, 2006.

Saïd, E. Orientalism. Nueva York, NY: Vintage Books, 1979.

Samaniego, M., Payàs, G., Zavala, J. M. e Garbarini, C. G. "La mediación lingüística oral en la frontera del biobío: fundamentos disciplinares e interdisciplinariedad en una investigación de base traductológica". Cuadernos de la Facultad de Humanidades y Ciencias Sociales de la Universidad Nacional de Jujuy, 42, (2012): 35-56. 22/04/2020 < http://revista.fhycs.unju.edu.ar/ revistacuadernos/index.php/cuadernos/article/view/88 $>$.

Shisheng, L. \& Shuang, L. "The role shift of the interpreter to a cultural mediator: From the perspective of cultural orientations and contexting". Babel, 58.2, (2012): 145-163.

Stolz, T., Vossmann, C. \& Dewein, B. Kolonialzeitliche Sprachforschung Die Beschreibung afrikanischer und ozeanischer Sprachen zur Zeit der deutschen Kolonialherrschaft. (En la serie Koloniale und Postkoloniale Linguistik / Colonial and Postcolonial Linguistics). Berlín, Alemania / Boston, MA: De Gruyter, 2011.

Umaña-Taylor, A. "Language brokering as a stressor for immigrant children and their families". In: M. Coleman y L. Ganong (Eds.), Points and counterpoints: Controversial relationship and family issues in the 21st century: An anthology: 157- 159. Los Angeles, CA: Roxbury, 2003. 
Tymoczko, M. Translation in the postcolonial context. Early Irish literature in English translation. Manchester, Reino Unido: St. Jerome Publishing, 1999.

Tymoczko, M. (Ed.). Translation, resistance, activism. Amherst, MA: University of Massachusetts Press, 2010.

Valdeón, R. A. Translation and the Spanish empire in the Americas. Amsterdam, Holanda: John Benjamins Publishing Company, 2014.

Vega Cernuda, M. Á.; Pulido Correa, M. L. (Eds.). El escrito misionero como mediación intercultural de carácter multidisciplinar. Madrid, España: Ommpress, 2016.

Venuti, L. The translator's invisibility: A history of translation, $2^{\text {a }}$ ed. Abingdon, Oxon, Reino Unido: Routledge, 2008.

Wierzbicka, A. "Translatability and the scripting of other peoples' 'souls". Australian Journal of Anthropology, 24. 1, (2013): 1-21.

Wierzbicka, A. "Language and Cultural Scripts". The Routledge Handbook of Language and Culture, F. Sharifian (Ed.), Abingdon, Reino Unido / Nueva York, NY: Routledge Taylor \& Francis Group, 2015, pp. 339-356.

Wright Carr, D. Ch. "La política lingüística en la Nueva España". Acta Universitaria, 17.3, (2007): 5-18.

Zimányi, K. "On impartiality and neutrality: a diagrammatic tool as a visual aid. The Journal of Translation and Interpreting Research". Missionary linguistics/ Lingüistica misionera. Amsterdam, Holanda: John Benjamins Publishing Company, 2009, pp. 55-70.

Zimmermann, K. "La construcción del objeto de la historiografía de la lingüística misionera". Missionary linguistics/Lingüística misionera, O. Zwartjes e E. Hovdhaugen (Eds.), Amsterdam, Holanda: John Benjamins Publishing Company, 2004, pp. 7-32. 
Zimmermann, K. \& Kellermeier-Rehbein, B. (Eds.). Colonialism and Missionary Linguistics. Berlín, Alemania/Boston, MA: De Gruyter, 2015.

Zwartjes, O. "The historiography of missionary linguistics. Present state and further research opportunities". Historiographia Linguistica, 39.2-3 (2012): 185242. 22/04/2020. < https://pure.uva.nl/ws/files/1863018/118471_MS_Zwartjes. pdf $>$.

Zwartes, O. \& Hovdhaugen, E. (Eds.). Missionary linguistics/Lingüística misionera. Selected papers from the First International Conference on Missionary Linguistics, Oslo, 13-16 March 2003. Amsterdam, Holanda: John Benjamins Publishing Company, 2004.

Zwartjes, O.; Zimmermann \& K. Schrader-Kniffki, M. (Eds.). Missionary linguistics/Lingüistica misionera $V$ : Translation theories and practices. Amsterdam, Holanda y Philadelphia, PA: John Benjamins Publishing Company, 2014.

Recebido em: 23/07/2020

Aceito em: 25/11/2020

Publicado em janeiro de 2021

Verónica Murillo Gallegos. E-mail: veramurillog@uaz.edu.mx. ORCID: https:// orcid.org/0000-0002-7561-3771.

Krisztina Zimányi. E-mail: krisztina.gto@gmail.com.

Anna María D’Amore. E-mail: adamore@uaz.edu.mx. ORCID: https://orcid. org/0000-0001-5348-5361.

Sara Lelis. E-mail: saralelis@gmail.com. ORCID: https://orcid.org/0000-00019471-7018. 